\title{
Obituary: Arvin S. Gibson
}

Arvin S. Gibson, a veteran near-death researcher and frequent contributor to this journal, died from complications following openheart surgery in Salt Lake City on the eve of Thanksgiving, November 24,2004 . He was only a few weeks short of his $80^{\text {th }}$ birthday when he died.

Gibson grew up in California, and served in the U.S. Army on Iwo Jima during World War II. After being discharged, he graduated from the University of California, Berkeley, with a degree in mechanical engineering. Much of his working career was devoted to research and development of nuclear energy, of which he was an articulate proponent until his death. Before his retirement in 1987, he was an Executive Vice President for Utah Power where he had been in charge of the construction of coal-fired power plants.

It was only after his retirement that Gibson began his second career as a near-death researcher, in which efforts he was assisted by his wife, Carol. Together they interviewed many near-death experiencers and eventually published several books on their research. Gibson's most important NDE books were Glimpses of Eternity (1992), Echoes of Eternity (1993), and Fingerprints of God (1999), but his other publications included autobiographical works and even a novel. At the time of his death, Gibson was working on his most ambitious book, dealing with the contributions made by Mormons to the field of neardeath studies. In this respect, Gibson was widely recognized to be the foremost authority on this subject.

Gibson held numerous teaching and service positions in The Church of Jesus Christ of Latter-day Saints, including Counselor in a Stake Presidency, Bishop, High Councilor, Elder's Quorum President and Sunday School Teacher. He leaves his wife, Carol, their four children, and thirteen grandchildren. 